\title{
UJI ANTIBAKTERI SUSU FERMENTASI KOMERSIAL PADA BAKTERI PATOGEN
}

\section{(EXAMINE ANTIBACTERIA ACTIVITY OF COMMERCIAL FERMENTED DAIRY PRODUCTS AGAINST PATHOGENS BACTERIA)}

\author{
Nur Khikmah \\ Akademi Analis Kesehatan Manggala Yogyakarta \\ Jl. Bratajaya No. 25, Sokowaten, Banguntapan, Bantul \\ e-mail: khikmahnr@gmail.com
}

\begin{abstract}
Abstrak
Penelitian ini bertujuan untuk mengetahui aktivitas antibakteri dari produk susu fermentasi komersial terhadap bakteri patogen. Uji antibakteri dilakukan menggunakan metode difusi sumuran. Aktivitas antibakteri susu fermentasi komersial diamati dengan terbentuknya zona jernih di sekeliling sumuran. Hasil penelitian menunjukkan bahwa yakult dan yoghurt probiotik mampu menghambat pertumbuhan bakteri patogen. Salmonella thypii merupakan bakteri patogen yang paling sensitif terhadap susu fermentasi. Daya hambat yakult dan yoghurt probiotik terhadap bakteri gram negatif lebih besar daripada bakteri gram positif. Yakult dengan kandungan Lactobacillus casei strain shirota mampu menghambat semua bakteri patogen, yaitu Salmonella thypii, Escherichia coli, Bacillus cereus, dan Staphylococcus aureus.
\end{abstract}

Kata kunci : antibakteri, bakteri patogen, probiotik, produk susu fermentasi

\begin{abstract}
The aim of this research was to examine antibacteria activity of commercial fermented dairy products against pathogens bacteria. The antibacteria activity was determined using the well diffusion method. The presence of antibacteria activity were shown by clear zone which formed around well containing fermented dairy products. The results show that yakult and probiotics yoghurt able to inhibit the growth of pathogens bacteria. The most sensitive pathogen bacteria to fermented dairy products was Salmonella thypii. Inhibition yakult and probiotics yoghurt against gram negative bacteria were greater than gram positive bacteria. Yakult containing Lactobacillus casei strain shirota was able to inhibit all pathogens bacteria, such as Salmonella thypii, Escherichia coli, Bacillus cereus, and Staphylococcus aureus.
\end{abstract}

Keywords: antibacteria activity, fermented dairy products, pathogens bacteria, probiotic

\section{PENDAHULUAN}

Susu merupakan emulsi lemak dalam air yang mengandung beberapa senyawa terlarut. Susu yang populer dan banyak dikonsumsi adalah susu sapi, karena populasi sapi perah relatif tinggi dan setiap sapi dapat menghasilkan susu 7-20 1/hari (Sunarlim, 2009). Susu sapi yang masih segar (mentah) pada umumnya terdiri dari air 87,5\%, protein 3\%, lemak 3-4\%, dan karbohidrat 
Jurnal Penelitian Saintek, Vol. 20, Nomor 1, April 2015

(laktosa) 5\%. Susu juga merupakan sumber kalsium, fosfor dan vitamin (Wibowo, 2002). Kandungan nutrisi yang tinggi pada susu menyebabkan susu menjadi substrat yang baik untuk pertumbuhan mikroba, sehingga susu menjadi rusak dan tidak layak dikonsumsi. Upaya untuk mengurangi adanya kontaminasi mikroba dan untuk memperpanjang waktu simpan susu adalah dengan pengawetan. Salah satu metode pengawetan susu yang prospektif adalah fermentasi susu.

Susu fermentasi didefinisikan sebagai produk susu yang melibatkan mikroba untuk menghasilkan flavour, warna, tekstur dan konsistensi yang diinginkan dan mampu mencegah lactose intolerance. Produk susu fermentasi yang umum dikonsumsi oleh masyarakat adalah yakult, yoghurt, kefir dan susu fermentasi berperisai. Yang membedakan masing-masing produk tersebut adalah jenis mikroba yang memfermentasi. Jenis mikroba yang berperan penting dalam fermentasi susu adalah kelompok bakteri asam laktat (BAL). Bakteri pada yakult adalah Lactobacillus casei, pada yoghurt adalah L. bulgaricus dan Streptococcus thermophillus. Pada kefir yang berperan adalah bakteri asam laktat dan khamir (Wibowo, 2002). Produk susu fermentasi pada saat ini banyak yang ditambah dengan bakteri probiotik, di antaranya L. acidophillus dan Bifidobacterium (Adriani, 2010).

Bakteri probiotik merupakan bakteri yang dikonsumsi dalam keadaan hidup, bertahan hidup dalam saluran pencernaan setelah melalui rintangan enzim pada air liur, asam lambung dan garam empedu, mampu melekat pada saluran pencernaan, tidak beracun dan tidak patogen (Kaplan and Hutkins, 2000). Penambahan bakteri probiotik ditujukan agar mempunyai efek fungsional bagi kesehatan (Irianto, 2013).

Selama proses fermentasi, bakteri asam laktat akan menghasilkan asam-asam organik (asam laktat, asam asetat, asam format), hidrogen peroksida, diasetil dan bakteriosin yang bersifat antibakteri (Daeschel, 1989). Hasil penelitian Suseno (2000) menunjukkan minuman probiotik yang terbuat dari nira siwalan dan L.casei dapat menghambat pertumbuhan bakteri patogen Staphylococcus aureus, Salmonella typhii dan Escherichia coli. Penelitian Purwijantiningsih (2011) juga menunjukkan bahwa minuman yoghurt sinbiotik mempunyai aktivitas antibakteri terhadap bakteri patogen enterik.

Pada saat ini, produk susu fermentasi komersial telah banyak beredar di pasaran dengan berbagai merk dan jenis. Produkproduk tersebut mengklaim berperan dalam melindungi sistem pencernaan dengan cara menghambat pertumbuhan bakteri patogen penyebab infeksi saluran pencernaan. Untuk itu penelitian ini dilakukan, sehingga akan diperoleh suatu informasi ilmiah tentang antibakteri susu fermentasi komersial, sehingga dapat meningkatkan ketertarikan masyarakat untuk mengkonsumsinya. Penelitian ini bertujuan untuk mengetahui 
aktivitas antibakteri dari produk susu fermentasi komersial terhadap bakteri patogen.

\section{METODE PENELITIAN}

Bakteri uji yaitu Bacillus subtilis, Staphylococcus aureus, Salmonella thypii dan Escherichia coli, masing-masing diinokulasikan pada media Nutrient Agar (NA) dan diinkubasi pada suhu kamar selama 24 jam. Masing-masing bakteri dibuat suspensi dalam larutan $\mathrm{NaCl}$ 0,85\% steril. Suspensi bakteri disesuaikan kekeruhannya dengan standar McFarland I, apabila kekeruhan suspensi masing-masing bakteri sama dengan kekeruhan suspensi standar berarti jumlah bakteri $108 \mathrm{CFU} / \mathrm{ml}$ (Reveny, 2011).

Aktivitas antibakteri susu fermentasi komersial diujikan terhadap kemampuannya menghambat pertumbuhan bakteri patogen menggunakan metode difusi sumuran (well diffusion methods) (Purwijantiningsih, 2011). Susu fermentasi komersial yang diujikan adalah susu fermentasi dengan kandungan bakteri yang berbeda. Jenisnya terdiri dari satu yakult, tiga yoghurt probiotik dan satu yoghurt murni.

Suspensi bakteri uji sebanyak $0,1 \%$ diinokulasikan pada cawan petri yang berisi $30 \mathrm{ml}$ media NA secara pour plate. Media ini didiamkan pada suhu $4^{\circ} \mathrm{C}$ selama $1-1,5$ jam selanjutnya dibuat sumuran sebanyak 6 sumuran dengan diameter $8 \mathrm{~mm}$. Pada 5 sumuran dimasukkan $60 \mu 1$ susu fermentasi yang berbeda dan 1 sumuran dimasukkan $60 \mu 1$ akuadest steril sebagai kontrol negatif. Selanjutnya diinkubasi pada suhu kamar selama 24 jam. Kemampuan penghambatan susu fermentasi terhadap bakteri patogen ditunjukkan adanya zona jernih di sekitar sumuran, diukur sebagai mm diameter zona jernih dikurangi diameter sumuran.

\section{HASIL DAN PEMBAHASAN}

\section{Uji Aktivitas Antibakteri Yoghurt ter- hadap Bakteri Patogen}

Berdasarkan uji aktivitas antibakteri menunjukkan bahwa susu fermentasi jenis yakult dan yoghurt probiotik mempunyai aktivitas antibakteri terhadap bakteri patogen yang diujikan. Sedangkan susu fermentasi jenis yoghurt murni tidak menunjukkan adanya aktivitas antibakteri (Gambar 1). Adanya aktivitas antibakteri tersebut ditunjukkan dengan terbentuknya zona penghambatan berupa zona jernih di sekitar sumuran yang diisi dengan yakult dan yoghurt probiotik.

Kemampuan antibakteri susu fermentasi terhadap patogen uji dikarenakan selama fermentasi bakteri asam laktat mampu menghasilkan senyawa antibakteri, di antaranya asam-asam organik (asam laktat, asam asetat), hidrogen peroksida, diasetil dan bakteriosin. Dalam penelitian ini belum diidentifikasi jenis senyawa antibakteri apa yang dihasilkan. Diameter zona jernih yang 


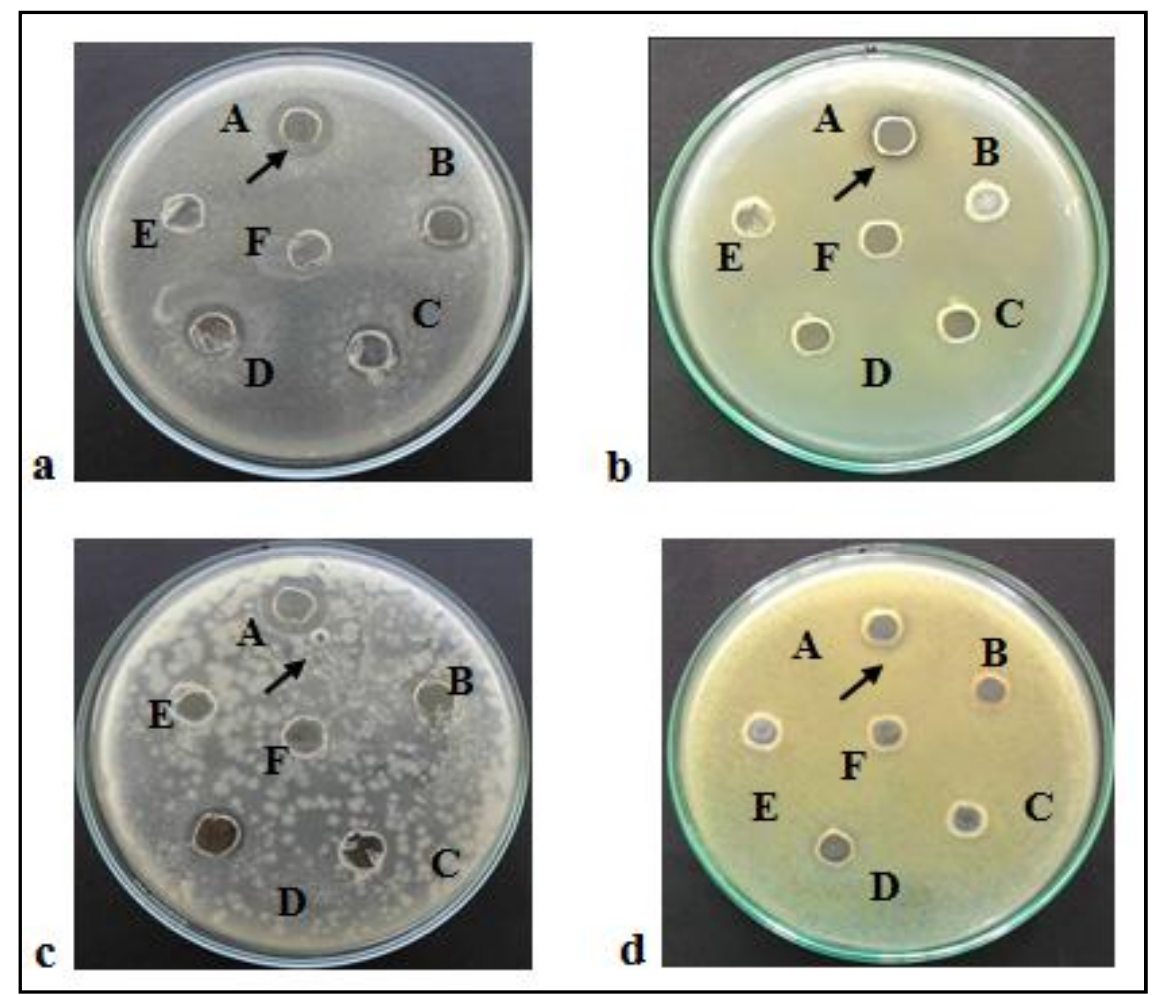

Gambar 1. Uji Antibakteri Susu Fermentasi Komersial terhadap Bakteri Patogen:

(a). S. thypii, (b). E. coli, (c). B. cereus, dan (d). S. aureus

\section{Keterangan :}

$\mathrm{A}=$ yakult, $\mathrm{B}-\mathrm{D}=$ yoghurt probiotik, $\mathrm{E}=$ yoghurt murni dan $\mathrm{F}=$ akuades steril (sebagai kontrol negatif). Tanda panah $(\boldsymbol{\nearrow})$ menunjukkan zona penghambatan susu fermentasi komersial terhadap bakteri patogen berupa zona jernih di sekitar sumuran.

dihasilkan oleh susu fermentasi komersial disajikan pada Tabel 1.

Berdasarkan hasil pada Tabel 1 menunjukkan bahwa susu fermentasi mem- punyai aktivitas antibakteri yang berbedabeda dalam menghambat bakteri patogen. Susu fermentasi A jenis yakult mempunyai aktivitas antibakteri terhadap semua bakteri

Tabel 1. Rata-rata Diameter Zona Jernih Susu Fermentasi Komersial terhadap Bakteri Patogen

\begin{tabular}{ccccc}
\hline \multirow{2}{*}{ Susu Fermentasi } & \multicolumn{4}{c}{ Diameter Zona Jernih (mm) } \\
\cline { 2 - 5 } & S. thypi & E. coli & B. cereus & S. aureus \\
\hline A & 6 & 3 & 4,4 & 2,4 \\
B & 2,4 & 0 & 0 & 0 \\
C & 2,2 & 0 & 0 & 0 \\
D & 4 & 0 & 1,4 & 0 \\
E & 0 & 0 & 0 & 0 \\
\hline
\end{tabular}

Keterangan : Data diameter zona hambat merupakan rata-rata dari 5 (lima) ulangan $\mathrm{A}=$ yakult, $\mathrm{B}-\mathrm{D}=$ yoghurt probiotik, $\mathrm{E}=$ yoghurt murni 
patogen uji. Susu fermentasi B dan C jenis yoghurt probiotik mempunyai aktivitas antibakteri terhadap S. thypii, yoghurt probiotik D mempunyai aktivitas antibakteri terhadap S. thypii dan B. cereus. Sedangkan yoghurt murni $\mathrm{E}$ tidak mempunyai aktivitas antibakteri terhadap semua bakteri patogen uji. Perbedaan penghambatan tersebut dikarenakan adanya perbedaan bakteri asam laktat yang memfermentasi susu, sehingga jumlah dan aktivitas senyawasenyawa antibakteri yang dihasilkan juga berbeda. Bakteri patogen uji juga mempunyai sensitifitas yang berbeda-beda terhadap senyawa antibakteri. Bakteri asam laktat yang terdapat dalam susu fermentasi disajikan pada Tabel 2.

Hasil penelitian juga menunjukkan bahwa $S$. thypii merupakan bakteri yang paling sensitif terhadap susu fermentasi. Hasil penelitian Kaboosi (2011), menunjukkan bahwa S. typhii dapat dihambat oleh yoghurt komersial dengan kategori penghambatan bakteriostatik dan bakteriosida. Yoghurt komersial tersebut mengandung Lactobacillus sp., Streptococcus sp. dan Bifidobacterium sp. Yesillik et al. (2011) dalam penelitiannnya,
S. typhimurium paling sensitif terhadap susu fermentasi, baik produk yoghurt murni (homemade dan komersial), kefir komersial, dan yoghurt probiotik.

\section{Aktivitas Antibakteri Susu Fermentasi terhadap Kelompok Bakteri Gram Positif dan Kelompok Bakteri Gram Negatif}

Bakteri yang tergolong dalam bakteri gram positif adalah B. cereus dan S. aureus, sedangkan yang tergolong bakteri gram negatif adalah S. thypii dan E.coli. Diameter zona jernih susu fermentasi terhadap kelompok bakteri gram positif dan kelompok bakteri gram negatif disajikan pada Tabel 3 .

Berdasarkan hasil pada Tabel 3, secara umum susu fermentasi komersial lebih mampu memberikan aktivitas antibakteri terhadap kelompok bakteri gram negatif daripada bakteri gram positif. Hasil penelitian Poeloengan (2012) menunjukkan bahwa bakteri gram negatif (S. thypii dan $E$. coli) cenderung lebih mudah dihambat oleh yoghurt probiotik dibandingkan bakteri gram positif (S. aureus dan B. cereus). Suseno (2000) minuman probiotik nira siwalan yang mengandung $L$. casei mempunyai aktivitas

Tabel 2. Bakteri Asam Laktat (BAL) dalam Susu Fermentasi Komersial

\begin{tabular}{cl}
\hline Susu Fermentasi & \multicolumn{1}{c}{ Bakteri Asam Lakat } \\
\hline A & L. casei shirota \\
B & Bifidobacterium BB-12, L. acidophilus LA-5, \\
C & S. thermophilus, L. bulgaricus, L. acidophilus, Bifidobacterium \\
D & L. acidophilius, Bifidobacterium animalis, L. casei \\
E & S. thermophilus, L. bulgaricus \\
\hline
\end{tabular}


Jurnal Penelitian Saintek, Vol. 20, Nomor 1, April 2015

Tabel 3. Rata-rata Diameter Zona Jernih Susus Fermentasi terhadap Kelompok Bakteri Gram Positif dan Kelompok Bakteri Gram Negatif

\begin{tabular}{ccc}
\hline \multirow{2}{*}{ Susu Fermentasi } & \multicolumn{2}{c}{ Diameter Zona Jernih $(\mathrm{mm})$} \\
\cline { 2 - 3 } & Bakteri Gram Positif & Bakteri Gram Negatif \\
\hline A & 3,4 & 4,5 \\
B & 0 & 1,2 \\
C & 0 & 1,1 \\
D & 0,7 & 2 \\
E & 0 & 0 \\
\hline
\end{tabular}

penghambatan terhadap $S$. thypii lebih besar daripada E. coli dan kurang mampu menghambat $S$. aureus.

Daya hambat susu fermentasi yang besar terhadap bakteri gram negatif diduga disebabkan oleh senyawa antibakteri yang berupa asam-asam organik (Branen and Davidson, 1993). Asam laktat dan asam asetat yang dihasilkan oleh bakteri asam lakatt merupakan antimikroba yang penting dan mempunyai aktivitas tinggi (Suskovic et al., 2010) serta mempunyai spektrum penghambatan yang luas (Rahayu, 2013).

Asam laktat mampu merusak permeabilitas bakteri gram negatif dengan merusak membran luar bakteri gram negatif. Asam laktat merupakan molekul yang larut dalam air sehingga mampu menembus ke dalam periplasma bakteri gram negatif melalui protein porin pada membran luar. Pelindung permeabilitas membran luar adalah lapisan lipopolisakarida (LPS) yang terletak pada permukaan membran dirusak oleh asam laktat. Dengan rusaknya membran luarsel, maka senyawa antimikroba yang lain, diantaranya diasetil, hidrogen peroksida dan bakteriosin akan masuk ke dalam membran sitoplasma merusak aktivitas intraseluler yang pada akhirnya dapat mematikan sel (Alakomi et al., 2000).

Padapenelitianini, kecilnyakemampuan daya hambat dari susu fermentasi terhadap bakteri gram positif dikarenakan kelompok bakteri gram positif mempunyai daya tahan terhadap kondisi asam. Cotter and Hill (2003) menyatakan bakteri gram positif mempunyai pertahanan terhadap kondisi asam melalui mekanisme pompa proton sehingga mampu menyeimbangkan $\mathrm{pH}$ dalam sel dan substrat antimikroba lainnya tidak dapat berpenetrasi ke dalam membran sitoplasma.

\section{KESIMPULAN}

Susu fermentasi komersial mempunyai aktivitas antibakteri yang berbeda-beda pada bakteri patogen. Daya hambat yakult dan yoghurt probiotik terhadap bakteri gram negatif lebih besar daripada bakteri gram 
positif. Salmonella thypii merupakan bakteri

patogen yang paling sensitif terhadap susu fermentasi. Yakult dengan kandungan Lactobacillus casei strain shirota mampu menghambat semua bakteri patogen, yaitu Salmonella thypii, Escherichia coli, Bacillus cereus, dan Staphylococcus aureus.

\section{DAFTAR PUSTAKA}

Adriani, L. 2010. Yoghurt Sebagai Probiotik, Dalam Soeharsono (eds). Probiotik. Bandung: Widya Padjadjaran.

Alakomi, H.L., Skytta, E., Saarela, M., Mattila-Sandholm, T., Latva-Kala, K and Helander, I.M. 2000. Lactic Acid Permeabilizes Gram-Negative Bacteria by Disrupting Outer Membrane. Applied and Environmental Microbiology, Vol. 66, No. 5., 2001-2005.

Branen, A.L. and Davidson, P.M. 1993. Antimicrobial in Foods. $2^{\text {nd }}$ ed. New York: Marcel Dekker, Inc.

Cotter, P.D and Hill, C. 2003. Surviving the Acid Test : Responses of Gram Positive Bacteria to Low $\mathrm{pH}$. Microbiology and Molecular Biology Review, Vol. 67, No. 3., 429-453.

Daeschel, M.A. 1989. Antimicrobial Substances from Lactic Acid Bacteria for Use as Food Preservaties. Food Technology, Vol. 43, No. 1., 164-167

Irianto, K. 2013. Mikrobiologi Medis. Bandung: Alfabeta.

Kaboosi, H. 2011. Antibacterial Effects of Probiotics Isolated from Yoghurts Against Some Common Bacterial Pathogens. African Journal of Micro- biology Research, Vol. 5, No. 25., 43634367.

Kaplan, H. and Hutkins, R.W. 2000. Fermentation of Fructooligosaccharides by Lactic Acid Bacteria and Bifidobacteria. Applied and Environmental Microbiology, Vol. 66, No. 6., 26822684.

Purwijantiningsih, E. 2011. Uji Antibakteri Yoghurt Sinbiotik terhadap Beberapa Bakteri Patogen Enterik. Biota, Vol. 16, No. 2., 173-177.

Poeloengan, M. 2012. Pengujian Yoghurt Probiotik pada Pertumbuhan Bakteri. Prosiding Semiloka Nasional Pros-pek Industri Sapi Perah Menuju Perdagangan Bebas 2020, Bogor: 303-307.

Rahayu, E.S., Yogeswara, A., Mariyatun, Haryono, P., Utami, I.S., Utami, T., Nurfiani, S and Cahyanto, M.N. 2013. Bakteri Asam Laktat Indigenous Berpotensi Probiotik dan Aplikasinya Untuk Produksi Susu Fermentasi. Prosiding Seminar Intensif Riset Sinas, Jakarta: 149-159.

Reveny, J. 2011. Daya Antimikroba Ekstrak dan Fraksi Daun Sirih Merah (Piper betle Linn). Jurnal ILMU DASAR, Vol. 12, No. 1., 6-12.

Suskovic, J., Kos, B., Beganovic, J., Pavunc, A.L., Habjanic, $\mathrm{K}$ and Matosic,S. 2010. Antimicrobial Activity-The Most Important Property of Probiotic and Stater Lactic Acid Bacteria. Food Technology Biotechnology, Vol. 48, No. 3., 296-307.

Sunarlim, R. 2009. Potensi Lactobacillus sp. Asal Dari Dadih sebagai Stater Pada Pembuatan Susu Fermentasi 
Jurnal Penelitian Saintek, Vol. 20, Nomor 1, April 2015

Khas Indonesia. Buletin Teknologi Pascapanen Pertanian, Vol. 5., 69-76.

Suseno, T.I.P., Surjoseputro, S., and Anita, K. 2000. Minuman Probiotik Nira Siwalan: Kajian Lama Penyimpanan terhadap Daya AntiMikroba Lactobacillus casei pada Beberapa Bakteri Patogen. Jurnal Teknologi Pangan dan Gizi, Vol. 1, No. 1., 1-13.

Wibowo, W. 2002. Bioteknologi Fermentasi Susu. Pusat Pengembangan Bio- teknologi. Universitas Muhammadiyah Malang.

Yesillik, S., Yildirim, N., Dikici, A., Yildiz and Yesillik, S. 2011. Antibacterial Effects of Some Fermented Commercial and Homemade Dairy Products and 0.9\% Lactic Acid Against Selected Foodborne Pathogens. Asian Journal of Animal and Veterinary Advances, Vol. 6, No. 2., 189-195. 